\title{
Formation of functional Tat translocases from heterologous
} components

\author{
Matthew G Hicks',2, David Guymer ${ }^{1,2}$, Grant Buchanan1 ${ }^{1}$, David A Widdick ${ }^{1,2}$, \\ Isabelle Caldelari ${ }^{1}$, Ben C Berks ${ }^{3}$ and Tracy Palmer*1,2
}

\begin{abstract}
Address: ${ }^{1}$ Department of Molecular Microbiology, John Innes Centre, Norwich NR4 7UH, UK, 2 School of Biological Sciences, University of East Anglia, Norwich NR4 7TJ, UK and ${ }^{3}$ Department of Biochemistry, University of Oxford, South Parks Road, Oxford OX1 3QU, UK

Email: Matthew G Hicks - matthew.hicks@bbsrc.ac.uk; David Guymer - d.guymer@uea.ac.uk; Grant Buchanan - grant.buchanan@bbsrc.ac.uk; David A Widdick - david.widdick@bbsrc.ac.uk; Isabelle Caldelari - i.caldelari@uea.ac.uk; Ben C Berks - ben.berks@bioch.ox.ac.uk; Tracy Palmer* - tracy.palmer@bbsrc.ac.uk

* Corresponding author
\end{abstract}

Published: 19 July 2006

BMC Microbiology 2006, 6:64 doi:10.1/86/147|-2180-6-64
Received: 24 April 2006

Accepted: 19 July 2006

This article is available from: http://www.biomedcentral.com/I47I-2/80/6/64

(c) 2006 Hicks et al; licensee BioMed Central Ltd.

This is an Open Access article distributed under the terms of the Creative Commons Attribution License (http://creativecommons.org/licenses/by/2.0), which permits unrestricted use, distribution, and reproduction in any medium, provided the original work is properly cited.

\begin{abstract}
Background: The Tat pathway transports folded proteins across the cytoplasmic membrane of bacteria and the thylakoid membrane of plants. In Eschericha coli, Tat transport requires the integral membrane proteins TatA, TatB and TatC. In this study we have tested the ability of tat genes from the eubacterial species Pseudomonas syringae, Streptomyces coelicolor and Aquifex aeolicus, to compensate for the absence of the cognate $E$. coli tat gene, and thus to form functional Tat translocases with E. coli Tat components.
\end{abstract}

Results: All three subunits of the Tat system from the Gram positive organism Streptomyces coelicolor were able to form heterologous translocases with substantive Tat transport activity. However, only the TatA and TatB proteins of Pseudomonas syringae were able to functionally interact with the $E$. coli Tat system even though the two organisms are closely related. Of the Tat components from the phylogenetically distant hyperthermophillic bacterium Aquifex aeolicus only the TatA proteins showed any detectable level of heterologous functionality. The heterologously expressed TatA proteins of $S$. coelicolor and $A$. aeolicus were found exclusively in the membrane fraction.

Conclusion: Our results show that of the three Tat proteins, TatA is most likely to show crossspecies complementation. By contrast, TatB and TatC do not always show cross-complementation, probably because they must recognise heterologous signal peptides. Since heterologouslyexpressed S. coelicolor TatA protein was functional and found only in the membrane fraction, it suggests that soluble forms of Streptomyces TatA reported by others do not play a role in protein export.

\section{Background}

There are two general pathways by which proteins are translocated across the cytoplasmic membranes of bacteria. The Sec pathway, which is ubiquitous, uses a thread- ing mechanism to transport unfolded polypeptides across the membrane, driven by the energy of ATP hydrolysis and the transmembrane proton gradient [1]. By contrast, the Tat pathway, which is encoded in about half of bacte- 
Table I: Percentage identities between E. coli Tat proteins and those from other eubacteria analysed in this study.

\begin{tabular}{lcc}
\hline Protein & $\begin{array}{c}\text { Length (amino } \\
\text { acids) }\end{array}$ & $\begin{array}{c}\text { Percentage identity to E. coli } \\
\text { homologue }\end{array}$ \\
\hline E. coli TatA & 89 & \\
P. syringae TatA & 91 & $60 \%$ over 48 residue overlap \\
S. coelicolor TatA & 95 & $36 \%$ over 40 residue overlap \\
A. aeolicus TatAI & 59 & $41 \%$ over 46 residue overlap \\
A. aeolicus TatA2 & 77 & $38 \%$ over 55 residue overlap \\
E. coli TatB & 171 & \\
P. syringae TatB & 153 & $40 \%$ over 71 residue overlap \\
S. coelicolor TatB & 161 & $33 \%$ over 55 residue overlap \\
A. aeolicus TatB & 117 & $23 \%$ over 102 residue overlap \\
E. coli TatC & 258 & \\
P. syringae TatC & 266 & $62 \%$ over 245 residue overlap \\
S. coelicolor TatC & 301 & $27 \%$ over 247 residue overlap \\
A. aeolicus TatC & 240 & $41 \%$ over 234 residue overlap \\
\hline
\end{tabular}

rial genomes sequenced so far, exports only pre-folded proteins. Substrate proteins are targeted to the Tat machinery by N-terminal signal peptides that harbour an almost invariant pair of arginine residues, which are critical for transport by the Tat pathway [reviewed in $[2,3]]$. Tat transport is driven solely by the protonmotive force [4].

Much of our understanding of protein transport by the Tat pathway has come from dual studies of the bacterial Tat pathway and the homologous $\Delta \mathrm{pH} /$ Tat pathway in plant thylakoids. The Tat system of Escherichia coli is comprised of the three major components, TatA, TatB and TatC, along with the minor component TatE which is a poorly expressed TatA orthologue [5-9]. Protein purification and cross-linking studies have identified two major types of Tat protein complexes in the membranes of E. coli, and analogous complexes have also been identified in thylakoid membranes. An equimolar complex of TatB and TatC, which contains multiple copies of each component, acts as the receptor for Tat substrates [10-12]. Site-specific cross-linking studies have implicated TatC as the component that recognizes the twin arginine motif of the substrate signal peptide [12]. The TatA protein forms a separate, highly heterogeneous complex, which varies in size because it contains different numbers of TatA protomers [13-16]. Examination of purified TatA complexes by negative stain electron microscopy reveal that it forms channel complexes with internal diameters large enough to accommodate folded substrate proteins [16]. Crosslinking studies suggest that TatA transiently associates with the substrate-bound TatBC complex during active protein translocation $[12,17,18]$.

The Tat systems of some Gram positive bacteria, exemplified by Bacillus subtilis, and some Archaea show a slightly different organization in that they lack TatB and therefore have translocases that are comprised solely of TatA and TatC [19]. The structural arrangement of subunits in these minimal Tat systems is currently unknown. However, a number of reports have indicated that at least some of the TatA protein of Haloferax volcanii, B. subtilis, and of the TatA and TatB proteins of Streptomyces lividans exists in a soluble form in the cytoplasmic fractions of these organisms [20-22]. These findings are significant, because they imply that the Tat systems in these prokaryotes may operate by a somewhat different mechanism to the canonical Tat systems of $E$. coli and plant thylakoids.

Previous studies looking at heterologous interactions during Tat transport have generally focused on the ability of Tat systems to recognize and transport foreign Tat substrates. Thus tat genes from different bacterial sources have been expressed in an E. coli strain deleted for all Tat components [23], which inform on the capacity of foreign translocases to recognize and transport E. coli Tat substrate proteins. Conversely, foreign Tat substrates have also been expressed in E. coli, to test the capacity of the system to recognize non-native signal peptides and passenger proteins [e.g. [24-28]]. However, very few studies have looked at the ability of individual Tat subunits to substitute for the absence of the cognate E. coli Tat component. It was reported that Helicobacter pylori tatA could partially complement the Tat defect of an E. coli $\Delta$ tatA $\Delta t a t E$ strain, but that $H$. pylori tatB could not substitute for $E$. coli tatB [8]. A very recent study suggested that the $P$. syringae pv tomato DC3000 tatC gene could also complement the E. coli tatC deletion strain [29].

In this work, we have systematically examined the ability of tat genes from three different bacterial species to compensate for the absence of the cognate E. coli tat gene. The organisms we selected for this study are Aquifex aeolicus, a thermophilic bacterium which forms the deepest branch in bacterial phylogeny, Streptomyces coelicolor, a Gram positive actinomycete and Pseudomonas syringae pv maculicola ES4326, which, like E. coli, is a gamma Proteobacterium. E. coli diverged from A. aeolicus approximately 4 billion years ago, from $S$. coelicolor approximately 3.2 billion years ago and from $P$. syringae approximately 1.3 billion years ago [30]. The percentage identities of the Tat proteins from these organisms with the paralogous E. coli Tat proteins is shown in Table 1 . Our results indicate that TatA proteins from any of these organisms are able to, at least partially, restore Tat activity to a strain lacking $E$. coli tatA and tatE. The P. syringae tatB and S. coelicolor tatB and tat $C$ genes were also able to complement the cognate $E$. coli tat deletion strains. Cell fractionation experiments demonstrate that the heterologously expressed TatA proteins of S. coelicolor and A. aeolicus are found exclusively in the membrane. 


\section{Results and discussion Experimental design}

Throughout these experiments we have used three different tests to assess functionality of the Tat system, each of which depends upon the transport of one or more native E. coli Tat substrates. E. coli tat mutants show a pleiotropic cell envelope defect due to an inability to export two Tatdependent periplasmic amidases, AmiA and AmiC, which are involved in cell wall remodelling [31,32]. Strains with an inactive Tat system are unable to grow on solid media in the presence of $2 \%$ SDS and therefore the ability to grow in the presence of this detergent is a qualitative indication of Tat function [33]. Likewise, E. coli is able to grow anaerobically using trimethylamine- $N$-oxide (TMAO) as an electron acceptor due to the Tat-dependent export of two enzymes, TMAO reductase (TorA, which is a soluble periplasmic protein) and dimethylsulphoxide (DMSO) reductase (DmsABC, which is membrane-bound, with its active site facing the periplasm [34]). Therefore the ability of strains to grow anaerobically on minimal media with glycerol as a carbon source and TMAO as sole electron acceptor is also a qualitative indicator of Tat functionality. Finally we have also assayed the activity of TMAO reductase in periplasmic extracts as a more quantitative assessment of the level of Tat functionality.

We have observed previously that the stoichiometry of Tat subunit expression is critical for activity of the Tat translocase. In particular, high level expression of TatB relative to TatA and TatC has a severe inactivating effect on the E. coli Tat system [8]. Thus in the following experiments we have routinely used $p c n B$ derivatives of each of the tat mutant strains, which drastically lowers the copy number of plasmids with the ColE1 replicon, typically to less than 5 copies per cell $[35,36]$.

\section{Heterologous expression of TatA proteins}

As shown in Fig 1, expression of the S. coelicolor or P. syringae TatA proteins in the E. coli tatA/tatE mutant strain resulted in significant restoration of Tat system function. Thus the tatA/tatE strain expressing either of these constructs showed robust growth in the presence of SDS (Fig 1A), with TMAO as sole terminal electron acceptor (Fig 1B) and had significant TMAO reductase (TorA) activity in the periplasmic fraction (Fig 1C). A. aeolicus is unusual in that it has a tandem duplication of tat $A$ genes, designated tatA1 and tatA2, which share $68 \%$ identity with each other over a 50 amino acid overlap. Expression of either or both of these tatA genes in the E. coli tatA/tatE strain was sufficient to support growth in the presence of SDS or with TMAO as sole electron acceptor (Fig 1A and 1B). However, the level of periplasmic TMAO reductase activity supported by these strains was not significantly above background (Fig 1C) indicating that the rate of TorA export was very low. None-the-less, these results suggest that TatA proteins from all of the three species tested are capable of some level of heterologous interaction with the E. coli TatBC proteins.

We have previously demonstrated that residue F39 of E. coli TatA is critical for TatA function and that mutation to anything other than tyrosine or tryptophan not only inactivates TatA function but also shows a dominant phenotype such that in co-expression studies it grossly affects the function of wild type TatA $[37,38]$. Surprisingly, S. coelicolor is one of a very few organisms that does not have phenylalanine at that position. Instead the amino acid at residue 40, which is the equivalent position in $S$. coelicolor TatA, is leucine. Although a leucine substitution of E. coli F39 is barely tolerated [38], the S. coelicolor TatA protein shows a significant level of functionality in E. coli. We tested whether the activity of $S$. coelicolor TatA could be enhanced by mutagenesis of L40 to phenylalanine. However, as shown in Fig 1C, this substitution did not significantly alter the functionality of $S$. coelicolor TatA in the E. coli system. We conclude that other residues in $S$. coelicolor TatA compensate for the presence of a leucine at this position.

\section{Heterologous expression of TatB}

The TatB protein, where present, is an essential component of the Tat system. It forms an equimolar complex with TatC and site-specific cross-linking analysis has indicated that it contacts Tat signal peptides close to the twin arginine motif, but also within the hydrophobic core $[10,12]$. In addition TatB has also been shown to co-purify with TatA, with which it shares some sequence homology [39]. It has been suggested to function as the adaptor between the TatBC complex and the TatA channel complex and therefore high level expression of TatB may disrupt Tat function by interfering with the co-assembly of the two individual complexes [8]. Since it interacts with each of the other Tat components and with Tat signal peptides, cross-complementation with TatB might be expected to be less efficient than with other Tat proteins. As shown in Fig 2A and 2B, the TatB proteins from either $S$. coelicolor or $P$. syringae permitted significant growth of the E. coli tatB strain, BØD-P, on selective media containing either SDS or TMAO. By contrast $A$. aeolicus TatB (coexpressed on a construct that also contains tatC) did not allow any significant growth of the E. coli tatB mutant on either medium. It should, however, be noted that we were not able to demonstrate expression of the A. aeolicus TatB protein in E. coli (data not shown) so it is possible that $A$. aeolicus TatB does not complement the E. coli tatB mutant because the protein is not produced. Fractionation of the tatB strain harbouring the different $t a t B$ genes and assay for periplasmic TMAO reductase activity, shown in Fig 2C, demonstrated that, as seen for TatA, the $S$. coelicolor TatB 
A

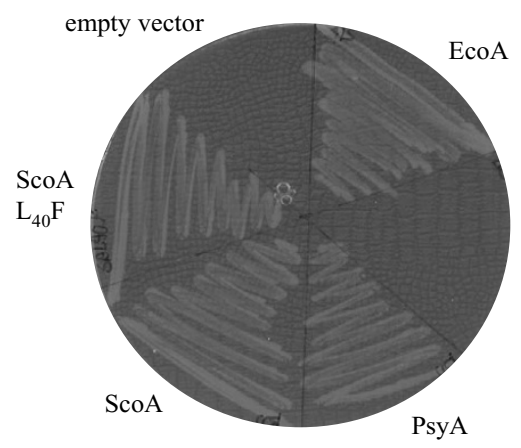

$\mathrm{B}$

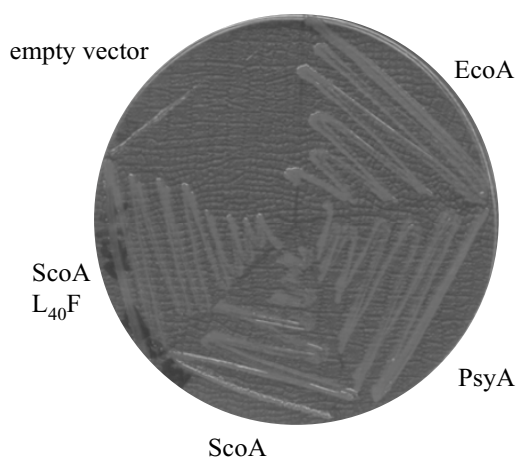

$\mathrm{C}$

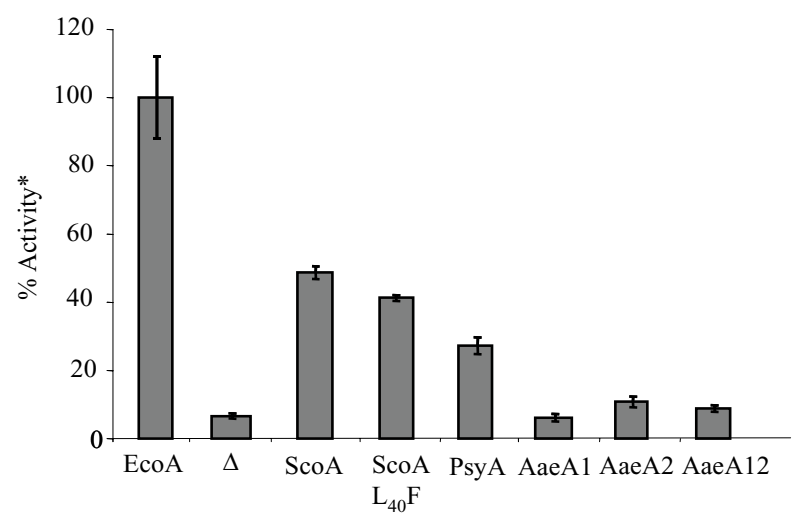

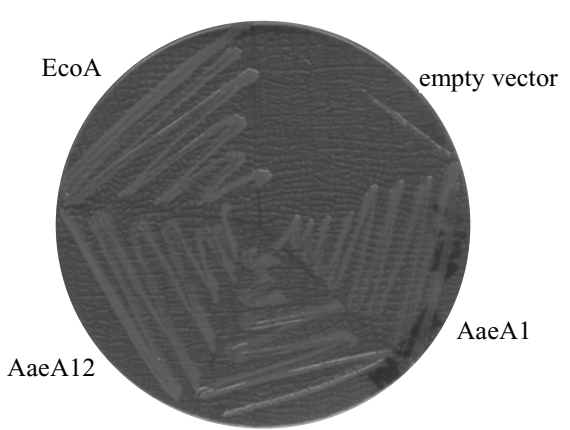

AaeA2

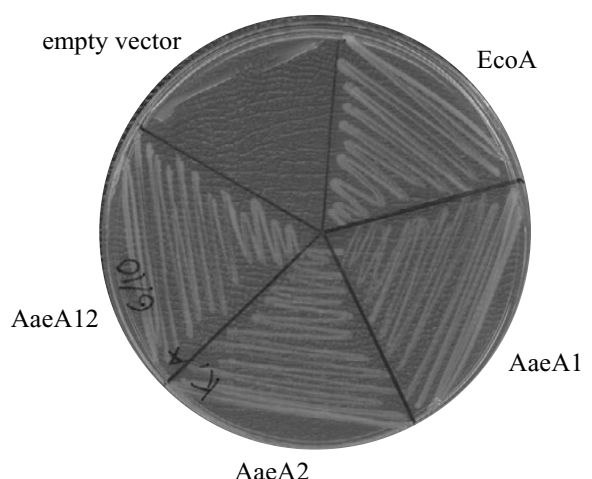

\section{Figure I}

Complementation of the E. coli $\triangle t a t A \Delta t a t E$, pcnB strain, JARVI6-P, with tatA genes from other bacteria. Strain JARVI6-P was transformed with either: $E$. coli tatA encoded on PFAT4 5 (EcoA), P. syringae tatA on plasmid pUniprom-PA (PsyA), S. coelicolor tatA from plasmid PUniprom-SA (ScoA), or the L40F derivative $\left(S c o A L_{40} F\right)$, A. aeolicus tatAl (AaeAl), tatA2 (Aae2) or tatAl2 (Aae I2) from PQEAQI, pQEAQ2 and PQEAQI2, respectively, or pBluescript (empty vector; marked as $\Delta$ in panel C). A. Growth of strains on LB medium containing $2 \%$ SDS. B. Growth of strains anaerobically on minimal glycerol TMAO medium. C. TMAO reductase activities from periplasmic fractions. $* 100 \%$ activity is taken as that determined from the periplasmic fraction of JARVI6-P carrying PFAT4I5 and corresponds to $1.3 \mu \mathrm{mol}$ benzyl viologen oxidised $/ \mathrm{min} / \mathrm{mg}$ protein. Error bars represent the standard error of the mean $(n=3)$. 
A

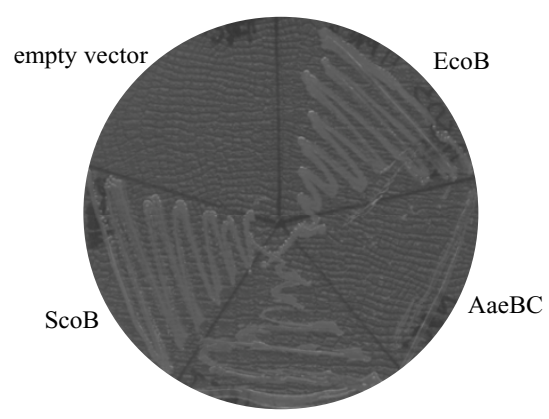

B

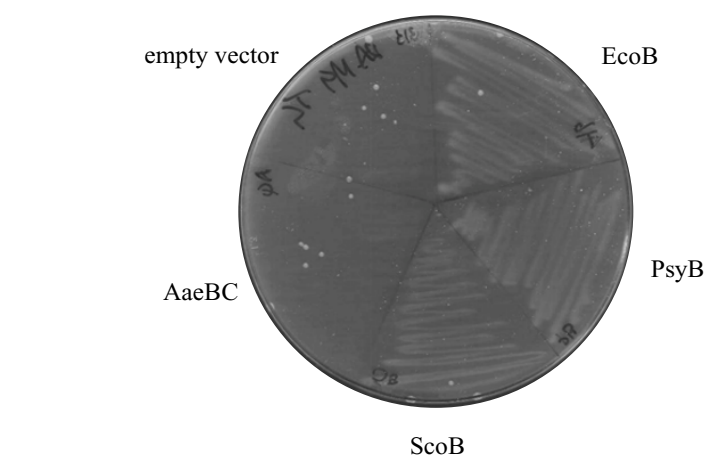

C

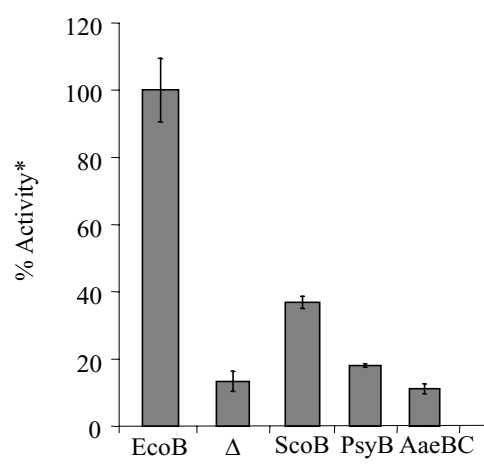

\section{Figure 2}

Complementation of the $E$. coli $\triangle t a t B, p c n B$ strain, BØD-P, with tat $B$ genes from other bacteria. Strain $B \varnothing D-P$ was transformed with either: $E$. coli tatB encoded on PFAT4I 6 (EcoB), $P$. syringae tatB on plasmid pUniprom-PB (PsyB), S. coelicolor tatB from plasmid pUniprom-SB (ScoB), A. aeolicus tatBC from plasmid $\mathrm{pQEAQBC}$ (AaeBC) or pBluescript (empty vector; marked as $\Delta$ in panel $C$ ). A. Growth of strains on LB medium containing $2 \%$ SDS. B. Growth of strains anaerobically on minimal glycerol TMAO medium. $C$. TMAO reductase activities from periplasmic fractions. $* 100 \%$ activity is taken as that determined from the periplasmic fraction of $B \varnothing D-P$ carrying pFAT4 16 and corresponds to $0.83 \mu \mathrm{mol}$ benzyl viologen oxi$\mathrm{dised} / \mathrm{min} / \mathrm{mg}$ protein. Error bars represent the standard error of the mean $(n=3)$. homologue gave the highest level of cross-species complementation.

It has been reported previously that the TatA and TatB proteins of $S$. lividans, an extremely close relative of $S$. coelicolor have partially overlapping activities [40]. We therefore tested the ability of the $S$. coelicolor $t a t B$ gene to complement the $E$. coli tat $A / E$ mutant strain, and likewise the $S$. coelicolor tatA gene to complement the E. coli tat $B$ mutant. In each case we saw no detectable complementation (results not shown).

\section{Heterologous expression of TatC}

The TatC protein is the largest and most conserved Tat component. It has been implicated as a specificity determinant for Tat-dependent secretion, most likely through recognition of Tat signal peptides [19,41]. Moreover, it has also been shown to cross-link with Tat signals when the site-specific cross-linker was incorporated adjacent to the twin arginines, suggesting that it probably recognizes the twin arginine motif of the signal peptide [12]. As shown in Fig 3A, B and 3C, only the TatC protein of S. coelicolor restored any detectable level of Tat activity to the $E$. coli tat $C, p c n B$ mutant strain. The tat $C$ genes of $P$. syringae and $A$. aeolicus (the latter co-expressed with tatB) completely failed to complement the tat $C$ strain, even for growth on SDS-containing medium, which is the most sensitive test for native Tat substrate export [42]. As shown in Fig 3D, despite its lack of functionality when expressed in the $E$. coli tat $C$ strain, the A. aeolicus his-tagged Tat $C$ protein encoded on our construct was clearly produced in $E$. coli and moreover was localized to the membrane fraction. We were not able to demonstrate whether the $P$. syringae TatC protein was expressed in these experiments because we lack a native antibody to the protein. However in the section below we demonstrate clearly that it is expressed from an analogous clone that also encodes $P$. syringae tat $A$ and tatB. Taken together our results suggest that $S$. coelicolor Tat subunits show the greatest level of cross-complementation, even though this organism is more distantly related to $E$. coli than is $P$. syringae.

\section{Heterologous expression of tatABC genes in a strain of $\mathrm{E}$. coli devoid of all Tat components}

The experiments described above where individual Tat subunits are expressed in $E$. coli examine the ability of that particular subunit to interact with $E$. coli Tat components, and, in addition, to recognize E. coli Tat signal peptides and substrate proteins. Under these circumstances, it is apparent that whilst all of the TatA proteins displayed some level of heterologous function, the $A$. aeolicus tat $B$ and $t a t C$ genes, and $P$. syringae tat $C$, failed to complement the cognate E. coli tat mutant strains. In order to determine whether this was because of an inability to form functional complexes with E. coli Tat components rather than 
A

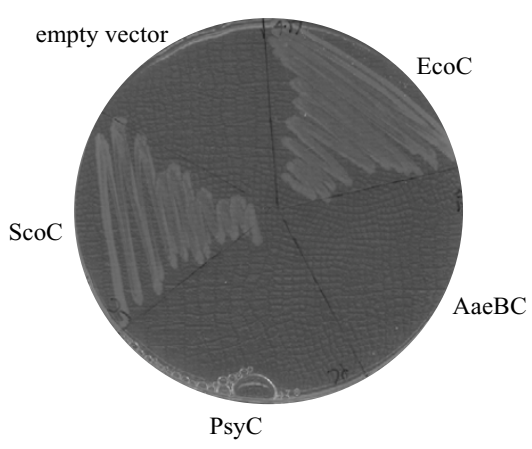

$\mathrm{B}$

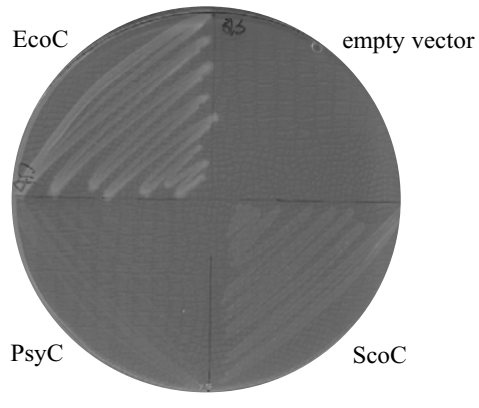

$\mathrm{C}$

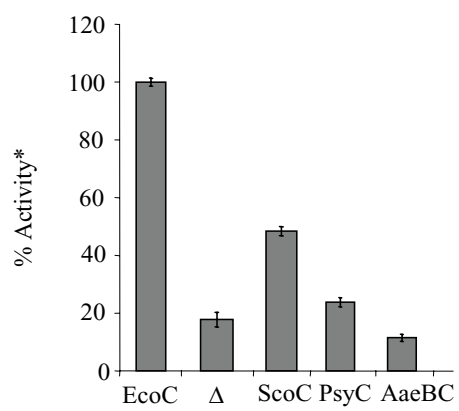

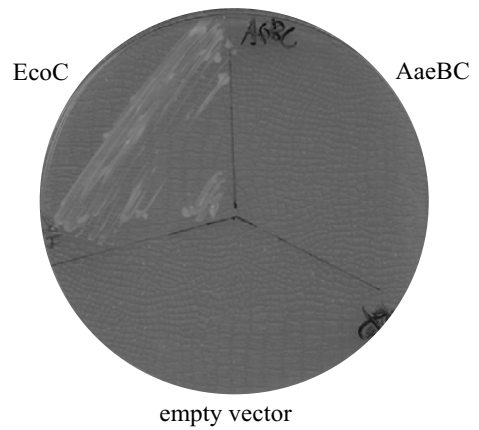

$\mathrm{D}$

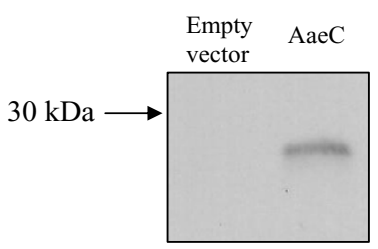

\section{Figure 3}

Complementation of the $E$. coli $\triangle t a t C$, pcnB strain, BILK0-P, with tatC genes from other bacteria. Strain BILK0-P was transformed with either: $E$. coli tat $C$ encoded on pFAT4I7 (EcoC), P. syringae tat $C$ on plasmid pUniprom-PC (PsyC), S. coelicolor tatC from plasmid pUniprom-SC (ScoC), A. aeolicus tatBC from plasmid PQEAQBC (AaeBC) or pBluescript (empty vector; marked as $\Delta$ in panel C). A. Growth of strains on LB medium containing $2 \%$ SDS. B. Growth of strains anaerobically on minimal glycerol TMAO medium. C. TMAO reductase activities from periplasmic fractions. *100\% activity is taken as that determined from the periplasmic fraction of BILK0-P carrying PFAT4I7 and corresponds to $0.79 \mu \mathrm{mol}$ benzyl viologen oxidised $/ \mathrm{min} / \mathrm{mg}$ protein. Error bars represent the standard error of the mean $(n=3)$. D. The A. aeolicus TatC protein is produced from clone PQEAQBC. Strain MI5 [PREP4] harboring either PQE60 (empty vector) or PQEAQBC (AaeC) was cultured in LB medium until OD600 of 0.4 was reached, after which production of the TatChis protein was induced by addition of I mM isopropyl- $\beta$ D-galactopyranoside (IPTG) for a further 2 hours. Membrane fractions were prepared, proteins $(50 \mu \mathrm{g}$ of total membrane protein), separated by SDS-PAGE, blotted onto nitrocellulose and developed using anti-penta-His antiserum. 
A

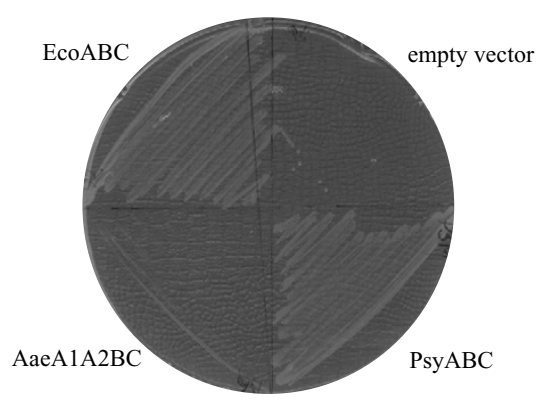

B

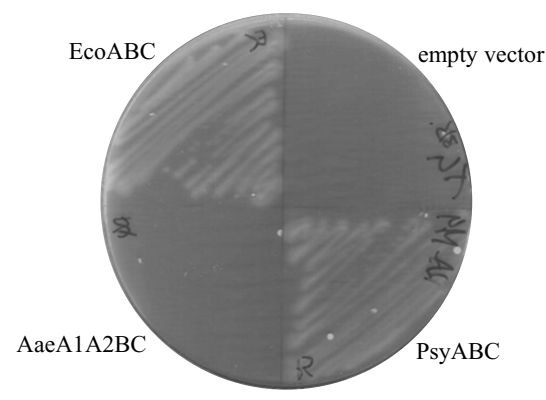

$\mathrm{C}$

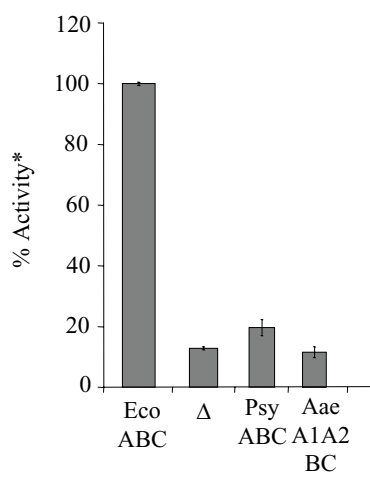

\section{Figure 4}

Complementation of the E. coli $\triangle \operatorname{tat} A B C D \triangle \operatorname{tat} E$, $p \subset n B$ strain, $D A D E-P$, with tat $A B C$ genes from other bacteria. Strain $D A D E-P$ was transformed with either: $E$. coli tat $A B C$ encoded on pUnitat2 (EcoABC), P. syringae tat $A B C$ on plasmid pUniprom-PABC (PsyABC), A. aeolicus tatA IA2BC from plasmid PFATAQ3 (AaeAIA2BC) or pBluescript (empty vector; marked as $\Delta$ in panel C). A. Growth of strains on LB medium containing $2 \%$ SDS. B. Growth of strains anaerobically on minimal glycerol TMAO medium. C. TMAO reductase activities from periplasmic fractions. $* 100 \%$ activity is taken as that determined from the periplasmic fraction of DADE-P carrying pUnitat2 and corresponds to $0.83 \mu \mathrm{mol}$ benzyl viologen oxidised $/ \mathrm{min} / \mathrm{mg}$ protein. Error bars represent the standard error of the mean $(n=3)$. an inability to interact with the test $E$. coli substrates, we examined whether transport activity was observed when the full set of heterologous Tat proteins were co-expressed. As shown in Fig 4, the P. syringae tat $A B C$ operon showed a low but detectable level of Tat function, indicating that the P. syringae TatC protein alone was not functional in the E. coli tatC strain most likely because it could not either interact with E. coli TatB and/or TatA, or because it was expressed at an inappropriate ratio with these proteins. An alternative explanation is that $P$. syringae tat $C$ in vector pUniprom-PC fails to express, although we note that it clearly does express from the same vector in the presence of $P$. syringae tat $A$ and tat $B$. Conversely, the $A$. aeolicus tat $A 1$, tat $A 2$, tat $B$ and $t a t C$ genes when expressed together from an artificial operon could not complement the E. coli total tat deletion strain. With the proviso that all of the A. aeolicus tat $A, \operatorname{tat} B$ and tat $C$ genes express in E. coli, this result suggests that the A. aeolicus Tat proteins are unable to recognize any of the AmiA, AmiC, TorA or DmsA signal peptides.

A summary of the results we obtained for all of the heterologous expression experiments is shown in Table 2.

\section{Heterologously expressed TatA proteins from $\mathbf{S}$. coelicolor and A. aeolicus are found exclusively in the membrane fraction}

One of the most striking reported differences between the Tat system of E. coli and of Gram positive (and archaeal) Tat systems is the presence of soluble forms of TatA in these latter organisms. Since we demonstrated above that the $S$. coelicolor and A. aeolicus TatA proteins show functionality in E. coli, it was reasonable to examine the subcellular location of these heterologously expressed TatA proteins. As shown in Fig 5A, all of the E. coli TatA protein was found in the membrane fraction. Strikingly, we also found all of the heterologously expressed S. coelicolor TatA and of the his-tagged A. aeolicus TatA1 and TatA2 proteins exclusively in the membrane fraction. Whilst we cannot rule out that any cytoplasmic forms of these heterologously-produced proteins might have been degraded, these observations indicate that at least when expressed in E. coli it is the membrane-bound protein that is functional for transport.

\section{Conclusion}

In this report we have tested the ability of Tat proteins from three different eubacterial species to form complexes with E. coli Tat components. Surprisingly, we found that it was the individual Tat proteins of $S$. coelicolor that consistently gave the highest level of Tat activity with the cognate E. coli tat deletion strains. Indeed each of $S$. coelicolor TatA, TatB and TatC formed heterologous Tat systems that were able to support $40-50 \%$ of the wild type E. coli Tat activity. The P. syringae TatA protein was able to restore reason- 
Table 2: Summary of Tat activity observed after heterologous expression of tat genes from different bacteria in $E$. coli tat mutant strains.

\begin{tabular}{|c|c|c|}
\hline E. coli strain & Plasmid-encoded gene(s) & $\begin{array}{l}\text { Functionality of } \\
\text { the Tat system }\end{array}$ \\
\hline \multirow[t]{6}{*}{ JARVI6-P( $\Delta t a t A / \Delta t a t E)$} & Eco tatA & ++ \\
\hline & Psy tatA & ++ \\
\hline & Sco tatA & ++ \\
\hline & $\operatorname{Scotat} A\left(\mathrm{~L}_{40} \mathrm{~F}\right)$ & ++ \\
\hline & Aae tatAl & + \\
\hline & Aae tatA2 & + \\
\hline \multirow[t]{4}{*}{$\mathrm{B} \varnothing \mathrm{D}-\mathrm{P}(\Delta t a t \mathrm{~B})$} & Eco tatB & ++ \\
\hline & Psy tatB & + \\
\hline & Sco tatB & ++ \\
\hline & Aae tatB & - \\
\hline \multirow[t]{4}{*}{ BILKO-P $(\Delta t a t C)$} & Eco tatC & ++ \\
\hline & Psy tatC & - \\
\hline & Sco tatC & ++ \\
\hline & Aae tatC & - \\
\hline \multirow[t]{3}{*}{$\mathrm{DADE}-\mathrm{P}(\triangle \mathrm{tat} A B C D / \Delta t a t \mathrm{t})$} & Eco tat $A B C$ & ++ \\
\hline & Psy tat $A B C$ & + \\
\hline & Aae tatA I A2tatBC & - \\
\hline
\end{tabular}

$1++$ indicates a high level of functionality $(>30 \%$ of the wild type level of periplasmic TMAO reductase activity, + indicates a lower level of functionality $(<30 \%$ of the wild type level of periplasmic TMAO reductase activity, but confers the ability to grow on solid media containing SDS or TMAO), - indicates a lack of activity (no growth on SDS or TMAO-containing plates).

able Tat function to the E. coli tatA/E mutant strain, but the tat $B$ gene complemented very poorly and $P$. syringae TatC was apparently completely inactive.

For each of the S. coelicolor and P. syringae cross-complementation experiments, individual Tat subunits were expressed from identical constructs, with transcription being driven by the constitutive E. coli tat promoter. It is probable that the heterologously expressed S. coelicolor tat genes are translated less efficiently than the $P$. syringae genes because of codon bias resulting from the high $\mathrm{G}+\mathrm{C}$ content of $S$. coelicolor DNA. Whilst we cannot completely rule out the possibility that there is a deleteriously high level of production of the individual $P$. syringae Tat proteins (but see below), it is none-the-less, striking that the S. coelicolor Tat proteins show a high level of cross-species activity. One possible explanation for this might be linked to the fact that the $S$. coelicolor has by far the largest predicted Tat secretome. Thus the S. coelicolor Tat system probably transports in excess of 150 Tat substrates, including some of the largest Tat substrates ever identified [4345]. It therefore must recognize many different twin arginine signal peptides and as a result one might expect that the S. coelicolor Tat components are less stringent than the P. syringae system in terms of signal peptide recognition and substrate size.

It should be noted that TatC from a different pathovar of $P$. syringae to that tested here [but with which it shares $97 \%$ amino acid sequence identity; [46]] was reported to show at least some minimal Tat activity in the E. coli tatC strain for transport of the Tat substrates AmiA and/or AmiC [29]. However in those experiments, the expression of $P$. syringae tat $C$ was from the strong ptac promoter on plasmid pTrc99A and was carried out in a $p c n B^{+}$background where plasmid copy number would be considerably higher. Thus it is likely that the levels of TatC between the two experiments would be significantly different which may account for the discrepancy in the observed activities.

It is striking to note that wherever cross-species complementation has been tested, TatA proteins always seem to retain some level of function in the heterologous host $[8,47]$. This suggests that the constraints on TatA function are less severe than those for TatB or TatC and is consistent with the fact that most of the interactions of heterologously expressed TatA would be self-oligomerisation to assemble into channel-forming multimers. By contrast, the constraints on cross-complementation with heterologously expressed $\mathrm{Tat} B$ or $\mathrm{Tat} C$ proteins are likely to be much more stringent since this would require the formation of equimolar complexes with the appropriate E. coli partner subunit, recognition of non-native signal peptides and associated conformational changes to promote assembly of the active translocase. It is notable that the $A$. aeolicus TatA proteins, which would normally be operating at temperatures of $80^{\circ} \mathrm{C}$, retain function when expressed in E. coli cells growing at $37^{\circ} \mathrm{C}$. Thus either the TatA protein does not change conformation during the transport cycle or the protein retains sufficient flexibility for function even at temperatures considerably lower than physiological.

A number of groups have reported in the literature the presence of soluble forms of the TatA and TatB proteins from Gram positive bacteria and archaea [20-22]. Fractionation and Western blotting showed quite clearly here that all of the heterologously expressed TatA proteins from S. coelicolor and A. aeolicus are found only in the membrane fraction. It is not clear why extra-membraneous forms of TatA/TatB are present in some organisms, but clearly since the $S$. coelicolor TatA protein [which is $100 \%$ identical to the S. lividans TatA protein; [48]] supports such a high level of Tat activity in E. coli then it is difficult to imagine how the mechanism of Tat transport at least between E. coli and Streptomycetes cannot be anything other than highly similar. 
A

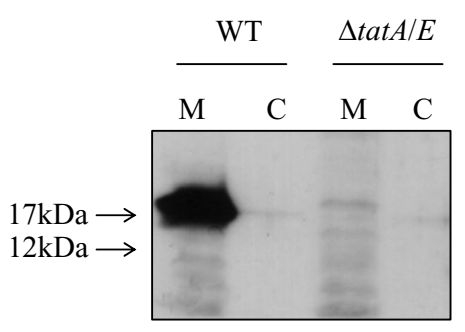

B

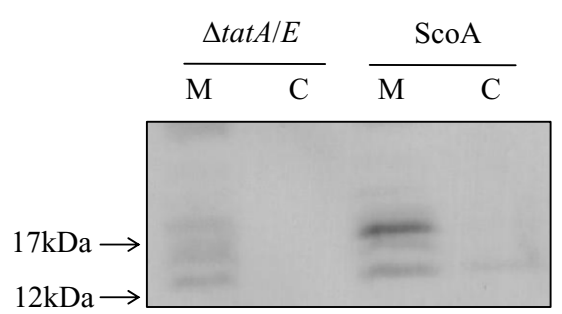

C

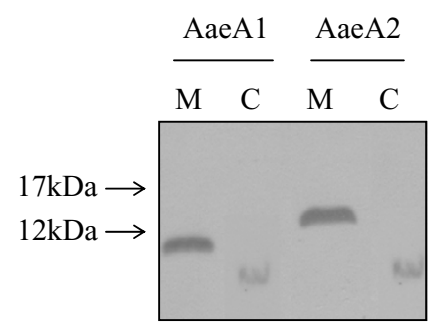

\section{Figure 5}

Heterologously expressed TatA proteins are located exclusively in the membrane. A. Strains MC4I00 (E. coli parental strain; tat $^{+}$; WT) and JARVI6-P (as MC4100, $\Delta$ tatA/ $\Delta$ tatE, $p c n B ; \Delta t a t A / E)$ were grown aerobically to late exponential phase in LB medium prior to harvesting and fractionation into membrane $(M)$ and soluble $(C)$ fractions. Samples were separated by SDS PAGE, electroblotted and probed with anti E. coli TatA antiserum. B. Strain JARVI6-P ( $\triangle$ tatA/E) or JARV I6-P carrying PUniprom-SA encoding $S$. coelicolor TatA (ScoA) were cultured, fractionated and blotted as above, and probed with anti S. coelicolor TatA peptide antiserum. C. Strain MI5 [PREP4] harboring either PQEAQI (AaeAI) or PQEAQ2 (AaeA2) encoding A. aeolicus TatAl or TatA2 with $\mathrm{C}$-terminal histags, respectively. Cells were cultured in LB medium until OD 600 of 0.4 was reached, after which expression of the TatA protein was induced by addition of I mM isopropyl- $\beta$-D-galactopyranoside (IPTG) for a further 2 hours. Cells were fractionated and blotted as above, and probed with anti pentahis antiserum. For each panel, membrane and soluble material from an equivalent amount of cells was loaded.

\section{Methods \\ Bacterial strains and growth conditions}

The E. coli strains and plasmids employed in this study are shown in Table 3. During all genetic manipulations, E. coli strains were grown aerobically in Luria-Bertani (LB) medium [49]. Concentrations of antibiotics were as described previously [6]. The growth phenotypes of mutants with TMAO as sole respiratory electron acceptor were determined on M9 minimal medium agar plates [49] supplemented with $0.5 \%$ glycerol and $0.4 \%$ TMAO and incubated in a gas jar under a hydrogen/carbon dioxide atmosphere. The SDS-resistance phenotype of mutants was tested on LB agar plates containing $2 \%$ SDS [33]. For TMAO reductase assay, cells were cultured in modified Cohen and Rickenberg medium [50], supplemented with addition of $0.2 \%$ glucose and $0.4 \%$ TMAO.

\section{Plasmid construction}

Plasmids pUniprom-PA, pUniprom-PB and pUnipromPC carry the P. syringae pv maculicola ES4326 tatA, tatB and tat $C$ genes, respectively, under the control of the E. coli tat promoter. They were cloned following amplification with primers GCGGCCGGATCCATGGGTATTTTTGACTGG and GCGCTCTAGATTAAACC TGGTCTTTGCGG to amplify tatA, GCGCGGGGATCCATGTTCGGTATCAGC and GCGCGCTCTAGATCATGGGGCTCGCGGTGGC to amplify $t a t B$, and GCGC GCGGATCCATGAGCGCTGATATCCCG and GCGCGCTCTAGATCACGGTGT GGTGGCGGGCGG to amplify tatC (restriction sites shown in bold) and plasmid pKS-PSMtatABC [46] as template. Each product was digested with $B a m \mathrm{HI}$ and $\mathrm{Xba \textrm {I }}$ and cloned into pUniprom [51] that had been similarly digested. Plasmids pUniprom-SA, pUniprom-SB and pUnipromSC carry the $S$. coelicolor tat $A, t a t B$ and tat $C$ genes, respectively, under the control of the E. coli tat promoter. They were cloned following amplification with primers GCGCGCGGATCCATGTTCGGAAGGCTCG GC and GCGCGCTCTAGATCAGCGCTTGGTCGTGTC to amplify tatA, GCGCG CGGATTCGTGTTCAATGACATAGGC and GCGCGCTCTAGATCAGGTGGCG TCCATGTC to amplify tatB, and GCGCGCGGATCCATGCCGCTCGCGGAACA C and GCGCGCTCTAGATCAGGTCACGTCGTCG to amplify tatC with $S$. coelicolor chromosomal DNA as template. Each product was digested with BamHI and $\mathrm{Xba \textrm {I }}$ and cloned into pUniprom that had been similarly digested.

Plasmids PFATAQ1 contains the tatA1 and tatA2 genes of A. aeolicus, under control of the lac promoter. The tatA1 and tatA2 genes, whose reading frames overlap, were amplified with the following primers: GCGCGCGAATTCCCСTTAAATTATTCTC TAAGGAGGC and GCGCGCGGATCCGCTGAGTTAAGCCTCTACCTTTTCC, with A. aeolicus chromosomal DNA (a kind gift of R. Huber) as template. The product was digested with EcoRI and BamHI 
Table 3: Strains and plasmids used in this study

\begin{tabular}{|c|c|c|}
\hline Bacterial Strains & Genotype & Source \\
\hline MC4I00 & $\mathrm{F}-\Delta$ lacUI 69 araDI $39 \mathrm{rpsL} / 50$ relAI ptsF rbs flbB530I & [58] \\
\hline $\mathrm{DH} 5 \alpha$ & $\phi 80 \mathrm{dlacZ} \Delta \mathrm{MI}$ 5, recAI, endAI, gyrA96, thi-I, hsdRI7(rK',mK+) supE44, relAI, deoR, $\Delta($ lacZYA-argF) UI69 & Promega \\
\hline MI5 & $\mathrm{F}-$, lac, ara, gal, $m t l$ & [59] \\
\hline JARVI6-P & As MC4I00 $\Delta$ tatALtatE pcnBI zad-98I::Tn I0d $\left(\mathrm{Km}^{\mathrm{r}}\right)$ & [8] \\
\hline BØD-P & As MC4I00 $\Delta$ tatB penBI zad-98I::Tn I0d $\left(\mathrm{Km}^{r}\right)$ & [8] \\
\hline BILKO-P & As MC4I00 $\Delta$ tatC penBI zad-98I::Tn I0d (Kmr) & This work \\
\hline DADE-P & As MC4I00 $\Delta$ tatABCD $\Delta$ tatE pcnBI zad-98I::Tn / 0d $\left(\mathrm{Km}^{\mathrm{r}}\right)$ & {$[60]$} \\
\hline \multicolumn{3}{|c|}{ 月 } \\
\hline PREP4 & $\mathrm{Kan}^{\mathrm{R}}, \mathrm{lacl}^{+}$ & Roche \\
\hline PBluescript (IIKS ${ }^{+}$) & $A m p^{R}$ & Stratagene \\
\hline PFAT4I5 & pBluescript carrying E. coli tatA & [8] \\
\hline PFAT4I6 & pBluescript carrying E. coli tatB & {$[8]$} \\
\hline pFAT4I7 & pBluescript carrying E. coli tatC & [8] \\
\hline pUniprom & Amp $p^{R}$ contains $E$. coli tat promoter and multiple cloning site & {$[51]$} \\
\hline PUniprom-PA & pUniprom carrying $P$. syringae tatA gene & This work \\
\hline pUniprom-PB & pUniprom carrying $P$. syringae tat $B$ gene & This work \\
\hline pUniprom-PC & pUniprom carrying $P$. syringae tat $C$ gene & This work \\
\hline pUniprom-PABC & pUniprom carrying $P$. syringae tat $A B C$ genes & This work \\
\hline pUniprom-SA & pUniprom carrying S. coelicolor tatA gene & This work \\
\hline PUniprom-SB & pUniprom carrying S. coelicolor tatB gene & This work \\
\hline pUniprom-SC & pUniprom carrying S. coelicolor tatC gene & This work \\
\hline PFATAQI & pBluescript carrying A. aeolicus tatA / and tat $A 2$ & This work \\
\hline pFATAQ2 & Bluescript carrying $A$. aeolicus tat $B C$ & This work \\
\hline PFATAQ3 & PBluescript carrying $A$. aeolicus tat $A$, tat $A 2$ and tat $B C$ & This work \\
\hline PQE70 & C-terminal His-tag expression vector & Qiagen \\
\hline PQEAQI & pQE70 carrying A. aeolicus tatA I & This work \\
\hline PQEAQ2 & PQE70 carrying A. aeolicus tatA2 & This work \\
\hline PQEAQBC & PQE70 carrying $A$. aeolicus tat $B C$ & This work \\
\hline PQEAQ I 2 & DQE70 carrying A. aeolicus tatA / and tatA2 & This work \\
\hline
\end{tabular}

and cloned into pBluescript that had been digested with the same enzymes. The A. aeolicus tatB gene is not annotated on the genome [52], however, a gene encoding a protein with 23\% identity (over 102 amino acid overlap) to $E$. coli TatB is found immediately upstream of the tatC gene (see Table 1 for identities of Tat proteins studied in this work with the paralogous E. coli protein), and we herein refer to it as tatB. Plasmid pFATAQ2 contains the tat $B$ and tat $C$ genes of $A$. aeolicus, under control of the lac promoter. The genes, whose reading frames also overlap, were amplified with primers GCGCGGATCCGGAAA GCAATCCCTATTAACGGAAG and GCGCTCTAGAGCTTATGCCTTTTGAATT TCCTTC, digested with BamHI and $X b a \mathrm{I}$ and cloned into pBluescript that had been predigested with the same enzymes. Plasmid PFATAQ3 contains an artificial operon encoding the tat $A 1,-A 2,-B$ and $C$ genes of $A$. aeolicus and was generated by subcloning the tatBC coding region from PFATAQ2 by digestion with $B a m \mathrm{HI}$ and $\mathrm{Xba \textrm {I }}$ and ligation into PFATAQ1 that had been similarly digested. For overproduction of the A. aeolicus Tat proteins with C-terminal hexahistidine affinity tags, the encoding tat genes were re-amplified and cloned into the overexpression vector $\mathrm{PQE70}$. Plasmid PQEAQ1 contains the gene encoding the TatA1 protein with a C-termi- nal histag and was amplified using primers GCGCGCATGCACTTTCCTCTGC CGTGGC and GCGCAGATCTTTTCACССТССТTTTTAACTTCC, and PFATAQ1 as template. The product was digested with SphI and BglII, and cloned into similarly digested pQE70. Plasmid pQEAQ2 is analogous to pQEAQ1 but encodes a tagged version of the TatA2 protein. It was cloned in a similar manner, using primers GCGC ACATGTTTTCCCGGCGGAATATCTATG and GCGCAGATCTAGCCTCTACC TTTTCCTTCTC to amplify the encoding gene. Plasmid pQEAQ12 carries both of the A. aeolicus tatA genes, with just TatA2 supplied with the C-terminal histag. The genes were amplified using primers GCGCGCATGCACTTTCCTCTGCCGTGGC and GC GCAGATCTAGCCTCTACCTTTTCСТTCTC, the product digested with SphI and $B g l I I$, and cloned into similarly digested pQE70.

All clones obtained from PCR amplified DNA were sequenced to ensure that no mutations (other than sitespecific mutations) had been introduced.

\section{Protein methods}

SDS-PAGE and immunoblotting were carried out as described $[53,54]$ and immunoreactive bands were visual- 
ized with the ECL detection system (Amersham Biosciences). Peptide antibodies to the S. coelicolor TatA protein were raised in rabbits, using a peptide of amino acid sequence CTSSRPVTEPTDTTKR, by Davids biotechnology (Regensburg, Germany). Antibodies to E. coli TatA have been described previously [39], the anti-pentahis antibody was obtained from Qiagen. Subcellular fractions for TMAO reductase activity measurements were prepared from small $(30 \mathrm{ml})$ cultures using the cold osmotic shock protocol [55]. TMAO:benzyl viologen oxidoreductase activity was measured as described previously [56]. Protein concentrations were estimated according to the method of Lowry et al. [57]. Preparation of membrane fractions was as described previously [6].

\section{Abbreviations}

Sec -general secretory pathway, Tat - Twin arginine translocation pathway, TMAO -trimethylamine- $\mathrm{N}$-oxide, TorA - TMAO reductase DMSO - dimethylsulphoxide, DmsABC - membrane-bound DMSO reductase.

\section{Authors' contributions}

MGH, DG, GB, IC and DW undertook experiments, BCB and TP wrote the manuscript.

\section{Acknowledgements}

We thank Drs Frank Sargent and Govind Chandra for helpful discussion, and Prof Robert Huber of the University of Regensburg for the gift of Aquifex aeolicus chromosomal DNA. This work was supported by the CEU project LHSG-CT-2004-005257, the BBSRC through a grant-in-aid to the John Innes Centre and a BBSRC-funded PhD studentship to MGH, the Swiss National Science Foundation through the award of a fellowship to IC and the Medical Research Council via a Senior Non-Clinical Fellowship award to TP.

\section{References}

I. Manting EH, Driessen AJ: Escherichia coli translocase: the unravelling of a molecular machine. Mol Microbiol 2000, 37:226-238.

2. Berks BC, Palmer T, Sargent F: The Tat protein translocation pathway and its role in microbial physiology. Adv Microb Physiol 2003, 47: 187-254.

3. Mori H, Cline K: Post-translational protein translocation into thylakoids by the Sec and $\Delta \mathrm{pH}$-dependent pathways. Biochim Biophys Acta 2001, I 541:80-90.

4. Yahr TL, Wickner WT: Functional reconstitution of bacterial Tat translocation in vitro. EMBO J 200I, 20:2472-2479.

5. Weiner JH, Bilous PT, Shaw GM, Lubitz SP, Frost L, Thomas GH, Cole JA, Turner RJ: A novel and ubiquitous system for membrane targeting and secretion of cofactor-containing proteins. Cell 1998, 93:93-101.

6. Sargent F, Bogsch E, Stanley NR, Wexler M, Robinson C, Berks BC, Palmer T: Overlapping functions of components of a bacterial Sec-independent protein export pathway. EMBO J 1998, I 7:3640-3650

7. Bogsch E, Sargent F, Stanley NR, Berks BC, Robinson C, Palmer T: An essential component of a novel bacterial protein export system with homologues in plastids and mitochondria. J Biol Chem 1998, 273:18003-18006.

8. Sargent F, Stanley NR, Berks BC, Palmer T: Sec-independent protein translocation in Escherichia coli: a distinct and pivotal role for the TatB protein. J Biol Chem 1999, 274:36073-36083.

9. Jack RL, Sargent F, Berks BC, Sawers G, Palmer T: Constitutive expression of Escherichia coli tat genes indicates an impor- tant role for the twin-arginine translocase during aerobic and anaerobic growth. J Bacteriol 200I, 183:180I-I804.

10. Bolhuis A, Mathers JE, Thomas JD, Barrett CM, Robinson C: TatB and TatC form a functional and structural unit of the twinarginine translocase from Escherichia coli. J Biol Chem 200I, 276:20213-20219.

II. Cline K, Mori H: Thylakoid $\Delta \mathbf{p H}$-dependent precursor proteins bind to a cpTatC-Hcfl 06 complex before Tha4-dependent transport. J Cell Biol 200I, I54:7I 9-729.

12. Alami M, Luke I, Deitermann S, Eisner G, Koch HG, Brunner J, Muller $M$ : Differential interactions between a twin-arginine signal peptide and its translocase in Escherichia coli. Mol Cell 2003, I 2:937-946.

13. Porcelli I, de Leeuw E, Wallis R, van den Brink-van der Laan E, de Kruijff B, Wallace BA, Palmer T, Berks BC: Characterisation and membrane assembly of the TatA component of the Escherichia coli twin-arginine protein transport system. Biochemistry 2002, 4I:13690-13697.

14. de Leeuw E, Granjon T, Porcelli I, Alami M, Carr SB, Müller M, Sargent F, Palmer T, Berks BC: Oligomeric properties and signal peptide binding by Escherichia coli Tat protein transport complexes. J Mol Biol 2002, 322: I I35-I I 46.

15. Oates J, Barrett CM, Barnett JP, Byrne KG, Bolhuis A, Robinson C The Escherichia coli twin-arginine translocation apparatus incorporates a distinct form of TatABC complex, spectrum of modular TatA complexes and minor TatAB complex. Mol Biol 2005, 346:295-305.

16. Gohlke U, Pullan L, McDevitt CA, Porcelli I, de Leeuw E, Palmer T, Saibil H, Berks BC: The TatA component of the twin-arginine protein transport system forms channel complexes of variable diameter. Proc Natl Acad Sci USA 2005, 102: $10482-10486$.

17. Mori J, Cline $\mathrm{K}$ : $\mathbf{A}$ twin arginine signal peptide and the $\mathbf{p H}$ gradient trigger reversible assembly of the thylakoid $\Delta \mathrm{pH} / \mathrm{Tat}$ translocase. I Cell Biol 2002, 157:205-210.

18. Dabney-Smith C, Mori H, Cline K: Oligomers of Tha4 organize at the thylakoid Tat translocase during protein transport. Biol Chem 2006, 28 I:5476-5483.

19. Jongbloed JDH, Grieger U, Antelmann H, Hecker M, Nijland R, Bron S, van Dijl JM: Two minimal Tat translocases in Bacillus. Mol Microbiol 2004, 54: I3 19-1325.

20. Pop O, Westermann M, Volkmer-Engert R, Schulz D, Lemke C, Schreiber S, Gerlach R, Wetzker R, Müller JP: Sequence-specific binding of prePhoD to soluble Tat $_{d}$ indicates protein-mediated targeting of the Tat export in Bacillus subtilis. J Biol Chem 2003, 278:38428-38436.

21. Dilks K, Giménez MI, Pohlschröder M: Genetic and biochemical analysis of the twin-arginine translocation pathway in halophilic archaea. J Bacteriol 2005, I87:8 I04-8II3.

22. De Keersmaeker S, Van Mellaert L, Schaerlaekens K, Van Dessel W, Vrancken K, Lammertyn E, Anné J, Geukens N: Structural organization of the twin-arginine translocation system in Streptomyces lividans. FEBS Letts 2005, 579:797-802.

23. Oates J, Mathers J, Mangels D, Kuhlbrandt W, Robinson C, Model K Consensus structural features of purified bacterial TatABC complexes. J Mol Biol 2003, 330:277-286.

24. Bruser T, Deutzmann R, Dahl C: Evidence against the doublearginine motif as the only determinant for protein translocation by a novel Sec-independent pathway in Escherichia coli. FEMS Microbiol Lett 1998, 164:329-336.

25. Angelini S, Moreno R, Gouffi K, Santini C, Yamagishi A, Berenguer J, Wu L-F: Export of Thermus thermophilus alkaline phosphatase via the twin-arginine translocation pathway in Escherichia coli. FEBS Letts 200I, 506: I03-107.

26. Blaudeck N, Sprenger GA, Freudl R, Wiegert T: Specificity of signal peptide recognition in Tat-dependent bacterial protein translocation. J Bacteriol 200I, 1 83:604-610.

27. Pop O, Martin U, Abel C, Müller JP: The twin-arginine signal peptide of PhoS and the TatA $A_{d} / C_{d}$ proteins of Bacillus subtilis form an autonomous Tat translocation system. J Biol Chem 2002, 277:3268-3273.

28. Snyder A, Vasil Al, Zajdowicz SL, Wilson ZR, Vasil ML: Role of the Pseudomonas aeruginosa PlcH Tat signal peptide in protein secretion, transcription, and cross-species Tat secretion system compatibility. J Bacteriol 2006, I88: $1762-1774$.

29. Bronstein PA, Marrichi M, Cartinhour S, Schneider DJ, DeLisa MP. Identification of a twin-arginine translocation system in Pseu- 
domonas syringae pv. tomato $\mathrm{DC} 3000$ and its contribution to pathogenicity and fitness. J Bacteriol 2005, 187:8450-846।.

30. Battistuzzi FU, Feijao A, Hedges SB: $\mathbf{A}$ genomic timescale of prokaryotic evolution: insights into the origin of methanogenesis, phototrophy, and the colonization of land. BMC Evol Biol 2004, 4:44-58.

3I. Ize B, Stanley NR, Buchanan G, Palmer T: Role of the Escherichia coli Tat pathway in outer membrane integrity. Mol Microbiol 2003, 48: II83-1193.

32. Bernhardt TG, de Boer PA: The Escherichia coli amidase AmiC is a periplasmic septal ring component exported via the twin-arginine transport pathway. Mol Microbiol 2003, 48: $|17|-|| 82$

33. Buchanan G, de Leeuw E, Stanley NR, Wexler M, Berks BC, Sargent $\mathrm{F}$, Palmer T: Functional complexity of the twin-arginine translocase TatC component revealed by site-directed mutagenesis. Mol Microbiol 2002, 43: I457-I470.

34. Stanley NR, Sargent F, Buchanan G, Shi J, Stewart V, Palmer T, Berks BC: Behaviour of topological marker proteins targeted to the Tat protein transport pathway. Mol Microbiol 2002, 43: $1005-1021$

35. Liu JD, Parkinson JS: Genetics and sequence analysis of the pcnB locus, an Escherichia coli gene involved in plasmid copy number control. J Bacteriol 1989, 171:1254-|26|.

36. Lee $P$ : Characterisation of the TatA and Tat $B$ proteins of the Escherichia coli Tat translocase. In PhD thesis University of East Anglia; 2003.

37. Hicks MG, de Leeuw E, Porcelli I, Buchanan G, Berks BC, Palmer T: The Escherichia coli twin-arginine translocase: conserved residues of TatA and Tat $B$ family components involved in protein transport. FEBS Letts 2003, 539:61-67.

38. Hicks MG, Lee PA, Georgiou G, Berks BC, Palmer T: Positive selection for loss-of-function tat mutations identifies critical residues required for TatA activity. I Bacteriol 2005, 187:2920-2925.

39. Sargent F, Gohlke U, de Leeuw E, Stanley NR, Palmer T, Saibil HR, Berks BC: Purified components of the Escherichia coli Tat protein transport system form a double-layered ring structure. Eur J Biochem 200I, 268:336I-3367.

40. De Keersmaeker S, Van Mellaert L, Lammertyn E, Vrancken K, Anné J. Geukens N: Functional analysis of TatA and TatB in Streptomyces lividans. Biochem Biophys Res Comm 2005, 335:973-982.

4I. Jongbloed JD, Martin U, Antelmann H, Hecker M, Tjalsma H, Venema G, Bron S, van Dijl JM, Muller J: TatC is a specificity determinant for protein secretion via the twin-arginine translocation pathway. J Biol Chem 2000, 275:4I350-4I357.

42. Lee PA, Buchanan G, Stanley NR, Berks BC, Palmer T: Truncation analysis of TatA and TatB defines the minimal functional units required for protein translocation. J Bacteriol 2002, 184:587|-5879.

43. Dilks K, Rose RW, Hartmann E, Pohlschroder M: Prokaryotic utilization of the twin-arginine translocation pathway: a genomic survey. J Bacteriol 2003, 185: I 478-I 483.

44. Bendtsen JD, Nielsen $\mathrm{H}$, Widdick D, Palmer T, Brunak S: Prediction of twin-arginine signal peptides. BMC Bioinformatics 2005, 6:167-175

45. Widdick DA, Dilks K, Chandra G, Bottrill A, Naldrett M, Pohlschro$\operatorname{der} \mathrm{M}$, Palmer T: The twin-arginine translocation pathway is a major route of protein export in Streptomyces coelicolor. 2006. submitted

46. Caldelari I, Mann S, Crooks C, Palmer T: The Tat pathway of the plant pathogen Pseudomonas syringae is required for optimal virulence. Mol Plant-Microbe Interact 2006, 19:200-2/2.

47. Bernhard M, Friedrich B, Siddiqui RA: Ralstonia eutropha TF93 is blocked in Tat-mediated protein export. | Bacteriol 2000 182:58I-588.

48. Schaerlaekens K, Schierová M, Lammertyn E, Geukens N, Anné J, van Mellaert L: Twin-arginine translocation pathway in Streptomyces lividans. J Bacteriol 200I, 183:6727-6732.

49. Sambrook J, Fritsch EF, Maniatis T: Molecular Cloning: A Laboratory Manual. 2nd edition. Cold Spring Harbor Press, Cold Spring Harbor, NY; 1989.

50. Cohen GN, Rickenberg HW: Concentration specifique reversible des amino acids chez Escherichia coli. Ann Inst Pasteur (Paris) 1956, $91: 693-720$.
51. Jack RL, Buchanan G, Dubini A, Hatzixanthis K, Palmer T, Sargent F: Coordinating assembly and export of complex bacterial proteins. EMBO J 2004, 23:3962-3972.

52. Berks BC, Sargent F, Palmer T: The Tat protein export pathway. Mol Microbiol 2000, 35:260-274.

53. Laemmli UK: Cleavage of structural proteins during the assembly of the head of bacteriophage T4. Nature 1970, 277:680-685.

54. Towbin H, Staehelin T, Gordon J: Electrophoretic transfer of proteins from polyacrylamide gels to nitrocellulose sheets: procedure and some applications. Proc Natl Acad Sci USA 1979, 76:4350-4354.

55. Stanley NR, Palmer T, Berks BC: The twin arginine consensus motif of Tat signal peptides is involved in Sec-independent protein targeting in Escherichia coli. I Biol Chem 2000, 257:11591-11596.

56. Silvestro A, Pommier J, Giordano G: The inducible trimethylamine- $\mathrm{N}$-oxide reductase of Escherichia coli $\mathrm{K}$ | 2: biochemical and immunological studies. Biochim Biophys Acta 1988, 954:I-13.

57. Lowry OH, Rosebrough NJ, Farr AL, Randall RJ: Protein measurements with the Folin phenol reagent. J Biol Chem I95I, 193:265-275.

58. Casadaban MJ, Cohen SN: Lactose genes fused to exogenous promoters in one step using a Mu-lac bacteriophage: in vivo probe for transcriptional control sequences. Proc Natl Acad Sci USA 1979, 76:4530-4533.

59. Villarejo MR, Zabin I: Beta-galactosidase from termination and deletion mutant strains. J Bacteriol 1974, I 20:466-474.

60. Lee PA, Greene NP, Buchanan G, Bond PJ, Punginelli C, Jack RL, Sansom MSP, Berks BC, Palmer T: Cysteine-scanning mutagenesis of the conserved domain of the twin-arginine translocase TatB component. 2006 in press.
Publish with Biomed Central and every scientist can read your work free of charge

"BioMed Central will be the most significant development for disseminating the results of biomedical research in our lifetime. "

Sir Paul Nurse, Cancer Research UK

Your research papers will be:

- available free of charge to the entire biomedical community

- peer reviewed and published immediately upon acceptance

- cited in PubMed and archived on PubMed Central

- yours - you keep the copyright

Submit your manuscript here:

http://www.biomedcentral.com/info/publishing_adv.asp
BiolMedcentral 